Original Research Article

\title{
Educational intervention to improve knowledge, attitude and practice of pharmacovigilance among nursing staff in tertiary care hospital
}

\author{
Sadhana Hingorani*, Chaitali Mehta, Paresh Gajera, S. K. Srivastava
}

Department of Pharmacology, Surat Municipal Institute of Medical Education and Research, Surat, Gujarat, India

Received: 19 April 2017 Accepted: 16 May 2017

*Correspondence to:

Dr. Sadhana Hingorani, Email: sadhanakh01@ gmail.com

Copyright: (C) the author(s), publisher and licensee Medip Academy. This is an openaccess article distributed under the terms of the Creative Commons Attribution NonCommercial License, which permits unrestricted noncommercial use, distribution, and reproduction in any medium, provided the original work is properly cited.

\begin{abstract}
Background: The present study was planned to assess the knowledge, attitude and practice among nursing staff and to evaluate the effect of educational intervention.

Methods: The questionnaire related with knowledge, attitude and practice (KAP) were given to nursing staff before and after the educational intervention in a tertiary care hospital. The data obtained were subjected to statistical analysis.

Results: The training given in different sessions has improved KAP among nursing staff. Ninety six percent of them responded correctly regarding who can report ADR as compared to pre training session (69\%). Regarding pharmacovigilance as purpose of safe use of medicines was responded by $71 \%$ after training as compared to $54 \%$ before training. In questions related to PvPI, $94 \%$ of nursing staff responded correctly about the scale to be used for causality assessment in comparison to $79 \%$ before training. Majority of them were of opinion that only unknown and serious ADR should be reported whereas after training they answered that all the ADR should be reported. A significant improvement has been noticed in questions related to attitude and practice.

Conclusions: The educational intervention to improve KAP among nursing staff has resulted in significant improvement.
\end{abstract}

Keywords: Adverse drug reaction, Nursing staff, Pharmacovigilance

\section{INTRODUCTION}

One of the major reasons of morbidity and mortality all over the world is adverse drug reactions. Adverse drug reactions are encountered commonly in daily practice, most of which are preventable. ${ }^{1,2}$ WHO defines ADR as a response to a drug which is noxious, unintended and which occurs at doses normally used in man for the prophylaxis, diagnosis or therapy of disease or for the modification of physiological function. Pharmacovigilance is defined by WHO: "The science and activities relating to the detection, assessment, understanding and prevention of adverse effects or any other drug related problem."
Primary source of information for Pharmacovigilance is from spontaneous reporting by health care professional. Under reporting of ADRs is a major problem affecting the safety of patient. It is important to enhance the awareness and knowledge of the health care professionals in India to improve the reporting. Several studies have been conducted to evaluate the knowledge, attitude and practice (KAP) towards Pharmacovigilance among clinicians, pharmacist, nurses. ${ }^{3-8}$ Nursing staff is important health care professional to detect and reporting ADR particularly for hospitalized patient as they are in contact with patient and available round the clock. Thus the present study was planned among nursing staff as mentioned below: 
- To assess the knowledge, attitude and practice among nursing staff.

a) To clarify problems regarding ADR reporting such as apprehension, legal issues, and lack of confidence etc.

b) To improve reporting of $\mathrm{ADR}$ by training nursing staff regarding ADR reporting and filling the ADR reporting form.

\section{METHODS}

This was a cross sectional, questionnaire based study which evaluated the KAP among nursing staff working in a tertiary care hospital.

Institutional Ethic Committee (IEC) clearance has been obtained. Total 55 nurses enrolled in this study. Training was arranged in four sessions. Questionnaires were prepared to assess the KAP of nursing staff which were designed and modified from previous studies. ${ }^{9}$ Questionnaire contain 25 questions out of which 15 questions were related to knowledge, 5 related to attitude and remaining 5 related to practice.

Initially pre KAP Questionnaire were given to all nurses and briefed about the purpose of the study. Then an educational training was given to them for a period of 2 hours. After this training session again post KAP Questionnaire were given to all the participants. Among 55 nurses 2 of them did not submitted post KAP Questionnaire so they were excluded from the study.

The result was analyzed question -wise. Each correct answer and positive response was given a score of 1 whereas negative response or wrong answer was given a score of 0 . More than 1 answer was allowed in some questions.

The questions of attitude and practice were analyzed by applying paired test and questions related to knowledge were analyzed by McNemars test and Chi square test.

\section{RESULTS}

\section{Questions related to knowledge were analyzed question- wise}

After training a significant improvement is seen in nursing staff regarding questions related to $\mathrm{ADR}$ reporting. Only $69 \%$ were aware about who can report ADR whereas after training $96 \%$ of them responded correctly. $71 \%$ of them told that the most important purpose of pharmacovigilance is to identify safety of drugs as compared to $54 \%$ (before training).

Only few of them (3\%) were aware regarding the programme under which blood component related ADR should be reported whereas after training $60 \%$ of them became aware.
Table 1: Questions related to ADR reporting.

\begin{tabular}{|c|c|c|c|c|}
\hline Questions & \multicolumn{2}{|c|}{$\begin{array}{l}\text { Pre training } \\
(\mathrm{n}=53)\end{array}$} & \multicolumn{2}{|c|}{$\begin{array}{l}\text { Post training } \\
(n=53)\end{array}$} \\
\hline Who can report ADR & 37 & $69 \%$ & $* 51$ & $96 \%$ \\
\hline $\begin{array}{l}\text { What is ADR } \\
\text { reporting system in } \\
\text { India }\end{array}$ & 38 & $71 \%$ & $* 50$ & $94 \%$ \\
\hline $\begin{array}{l}\text { Most important } \\
\text { purpose of } \\
\text { Pharmacovigilance is }\end{array}$ & 29 & $54 \%$ & $* 38$ & $71 \%$ \\
\hline $\begin{array}{l}\text { Rare ADR can be } \\
\text { identified in which } \\
\text { phase of clinical trial }\end{array}$ & 16 & $30 \%$ & 33 & $62 \%$ \\
\hline $\begin{array}{l}\text { Under which } \\
\text { programme ADR due } \\
\text { to blood component } \\
\text { is reported }\end{array}$ & 02 & $4 \%$ & $* 32$ & $60 \%$ \\
\hline $\begin{array}{l}\text { Pharmacovigilance } \\
\text { center at SMIMER, } \\
\text { Surat is a ADR } \\
\text { Monitoring Center }\end{array}$ & 23 & $43 \%$ & 42 & $79 \%$ \\
\hline
\end{tabular}

$* \mathrm{P}<0.05$ - significant (Chi square test) (difference between preand post training value)

\section{Questions related to pharmacovigilance programme of India}

Table 2: Questions related to pharmacovigilance programme of india.

\begin{tabular}{|lllll|}
\hline & \multicolumn{2}{c}{$\begin{array}{l}\text { Pre training } \\
\text { Questions }\end{array}$} & \multicolumn{2}{c|}{$\begin{array}{l}\text { Post training } \\
(\mathbf{n}=\mathbf{5 3})\end{array}$} \\
\hline Define ADR & 18 & $33 \%$ & 33 & $62 \%$ \\
\hline $\begin{array}{l}\text { Define } \\
\text { Pharmacovigilance }\end{array}$ & 14 & $26 \%$ & $* 25$ & $47 \%$ \\
\hline $\begin{array}{l}\text { Which scale is used } \\
\text { to establish causality } \\
\text { of ADR }\end{array}$ & 42 & $79 \%$ & $* 50$ & $94 \%$ \\
\hline $\begin{array}{l}\text { Which is web based } \\
\text { ICSR system for } \\
\text { reporting ADR }\end{array}$ & 04 & $7 \%$ & 47 & $88 \%$ \\
\hline $\begin{array}{l}\text { Who co-ordinate } \\
\text { Pharmacovigilance } \\
\text { programme of India }\end{array}$ & 08 & $15 \%$ & $* 19$ & $35 \%$ \\
\hline $\begin{array}{l}\text { Which regulatory } \\
\text { body is responsible } \\
\text { for monitoring of } \\
\text { ADR }\end{array}$ & 08 & $15 \%$ & $* 29$ & $54 \%$ \\
\hline $\begin{array}{l}\text { Which is regional } \\
\text { Pharmacovigilance } \\
\text { center in western } \\
\text { region }\end{array}$ & 02 & $3 \%$ & $* 30$ & $56 \%$ \\
\hline $\begin{array}{l}\text { Where is } \\
\text { International center } \\
\text { of ADR monitoring } \\
\text { located }\end{array}$ & 01 & $2 \%$ & 51 & $96 \%$ \\
\hline
\end{tabular}

$* \mathrm{P}<0.05$ - significant (Chi square test) (difference between pre and post training value) 
Ninety four percent of nursing staff responded correctly about which scale is used to establish causality of ADR as compared to $79 \%$ before training. Only $3 \%$ of them were aware regarding the location of Pharmacovigilance Centre in western region whereas after training $56 \%$ of them became aware. Only $2 \%$ of them were aware about International monitoring Centre before training whereas $96 \%$ were aware after training.

\section{Opinion about which ADR to be reported}

Before training majority of them were of opinion that only unknown and serious ADR should be reported whereas after training they were of opinion that known as well as nonserious ADR should also be reported. There was significant change in opinion regarding frequent, rare and spontaneous reporting of ADR.

Table 3: Opinion about which ADR should be reported.

\begin{tabular}{|lcccc|}
\hline Questions & \multicolumn{2}{c}{ Pre training } & \multicolumn{2}{c|}{ Post training } \\
\hline Known & 08 & $15 \%$ & 42 & $79 \%$ \\
\hline Unknown & 27 & $50 \%$ & $* 40$ & $75 \%$ \\
\hline Serious & 19 & $35 \%$ & 28 & $52 \%$ \\
\hline Nonserious & 06 & $11 \%$ & 26 & $49 \%$ \\
\hline Frequent & 08 & $15 \%$ & $* 12$ & $22 \%$ \\
\hline Rare & 09 & $17 \%$ & $* 11$ & $21 \%$ \\
\hline Spontaneous & 17 & $32 \%$ & $* 16$ & $30 \%$ \\
\hline
\end{tabular}

*P $<0.05$ significant (Chi square test) (difference between pre and post training value)

\section{Question related to attitude and practice}

A significant improvement has been noticed in questions related to Attitude and Practice (Table 4).

Table 4: Comparing the mean score of attitude and practice before and after intervention.

\begin{tabular}{|lll|}
\hline Factor & Pre training & Post training \\
\hline Attitude & $1.92 \pm 0.78$ & $* 2.43 \pm 0.77$ \\
\hline Practice & $4.33 \pm 0.80$ & $* 4.54 \pm 0.72$ \\
\hline
\end{tabular}

$* \mathrm{P}<0.05$ - significant (paired ' $\mathrm{t}$ ' test) (difference between pre and post training value)

\section{Factors which encourage them to report ADR}

Seventy one percent of them told that only serious reactions to be reported as compared to $58 \%$ before training. $66 \%$ of them felt that reaction to a new drug to be reported as compared to $62 \% .43 \%$ of them told unusual reaction to be reported as compared to $30 \%$.

\section{Factors which discourage them to report ADR}

Most of the nursing staff was able to understand various reasons for non reporting of $\mathrm{ADR}$ after the training sessions (Table 6).
Table 5: Factors that may encourage reporting of ADR.

\begin{tabular}{|lcccc|}
\hline & \multicolumn{2}{c}{ Pre training } & \multicolumn{2}{c|}{ Post training } \\
\hline Serious reaction & 31 & $58 \%$ & $* 38$ & $71 \%$ \\
\hline Unusual reaction & 16 & $30 \%$ & $* 23$ & $43 \%$ \\
\hline $\begin{array}{l}\text { If the reaction to a } \\
\text { new drug }\end{array}$ & 33 & $62 \%$ & $* 35$ & $66 \%$ \\
\hline Certainly an ADR & 18 & $33 \%$ & 25 & $47 \%$ \\
\hline $\begin{array}{l}\text { If the reaction was } \\
\begin{array}{l}\text { well recognised for a } \\
\text { particular drug }\end{array}\end{array}$ & 19 & $35 \%$ & $* 20$ & $37 \%$ \\
\hline
\end{tabular}

$* \mathrm{P}<0.05$ - significant (Chi square test) (difference between pre and post training value)

Table 6: Factors that may discourage reporting of ADR.

\begin{tabular}{|llccc|}
\hline & Pre training & \multicolumn{2}{c|}{ Post training } \\
\hline $\begin{array}{l}\text { No remuneration for } \\
\text { reporting }\end{array}$ & 05 & $9 \%$ & 10 & $* 18 \%$ \\
\hline $\begin{array}{l}\text { Lack of time to report } \\
\text { ADR }\end{array}$ & 25 & $47 \%$ & 36 & $68 \%$ \\
\hline $\begin{array}{l}\text { A single unreported } \\
\text { case may not affect } \\
\text { ADR database }\end{array}$ & 08 & $15 \%$ & 15 & $* 28 \%$ \\
\hline $\begin{array}{l}\text { Difficult to decide } \\
\text { whether ADR has } \\
\text { occurred or not }\end{array}$ & 23 & $43 \%$ & 30 & $56 \%$ \\
\hline $\begin{array}{l}\text { Concern that report } \\
\text { may be wrong }\end{array}$ & 07 & $13 \%$ & 16 & $* 30 \%$ \\
\hline $\begin{array}{l}\text { Concern that reporting } \\
\text { may create } \\
\text { unnecessary problem }\end{array}$ & 09 & $17 \%$ & 21 & $* 39 \%$ \\
\hline $\begin{array}{l}\text { Lack of confidence to } \\
\text { discuss the ADR with } \\
\text { other colleagues }\end{array}$ & 06 & $11 \%$ & 12 & $* 22 \%$ \\
\hline
\end{tabular}

$* \mathrm{P}<0.05$ - significant (Chi square test) (difference between pre and post training value)

\section{DISCUSSION}

The present study was a question based study which assessed KAP of nursing staff towards ADR. After educational intervention, it shows that there was improvement of KAP towards pharmacovigilance. Most of the nursing staff were not aware about Pharmacovigilance Programme of India (PvPI) and its co-ordinating centre.

In our study, it shows that nursing staff had poor knowledge about ADR. Similar results were observed in other studies. ${ }^{10}$ Most of the nursing staff felt that the most common reason for reporting of ADR was improvement of patients safety. Other similar studies were conducted which compared KAP of doctors and nurses. ${ }^{9}$ Similar result was seen in other study conducted by Desai et al. ${ }^{3}$ 
In our study we included educational training to nurses which shows significant improvement in KAP. Similar study was conducted by Nazli Sencan which concluded that to create reporting culture CMEs are necessary for health care professionals. ${ }^{9}$

Another study conducted by Sunita Kumari at a tertiary care centre showed that there is lack of awareness among nurses and there is need for educational intervention to increase their knowledge and awareness and to incorporate the gained knowledge in practice. ${ }^{10}$

Nursing staff should be trained adequately because they are first person to come in contact in the in-patient department when ADR occurs. Training should be given to all nursing staff in tertiary care hospital. Continuous training sessions were arranged in our centre to train most of the nursing staff adequately. Apprehension regarding legal issues can only be solved by giving adequate training.

A metanalysis which concluded that there was enormous gap of KAP towards pharmacovigilance and ADR reporting, particularly pharmacovigilance practice in India. So there is urgent need for educational awareness. ${ }^{11}$

\section{Limitations}

Limitation of our study was that we have taken 55 nursing staff in our study but this was a preliminary study. All nursing staff should be given training in future and it is recommended to include PvPI in teaching curriculum of nursing students.

\section{CONCLUSION}

The training given in different session has improved the knowledge, attitude and practice among nursing staff. After training, there was marked improvement in knowledge related questions like who can report ADR and how to fill ADR reporting form. Apprehensions regarding legal and other issues related with reporting of ADR have been alleviated/solved.

Funding: No funding sources

Conflict of interest: None declared

Ethical approval: The study was approved by the Institutional Ethics Committee

\section{REFERENCES}

1. Mc Donnel PJ, Jacob MR. Hospital admissions resulting from preventable ADR. Ann aharmacoether. 2002:36;1331-6.

2. Bates DW, Cullen DJ, Laird N. Incidence of ADR events and potential adverse drug events and implication for prevention. J Am Med Assoc. 1995;274;29-34.

3. Desai CK, Iyer G, Panchal J. An evaluation of knowledge, attitude and practice of adverse drug reaction reporting among prescribers at a tertiary care hospital. Perspective in clinical research. Oct-dec 2011;2(4):129.

4. Doshi MS, Patel PP. Intensive monitoring of adverse drug reactions in hospitalized patients of two medical units at a tertiary care teaching hospital India Journal of Pharmacology and Pharmacotherapeutics. October-December. 2012;3(4):308.

5. Dang A, Bhandare PN. Profile of Voluntary Reported Adverse Drug Reactions at a Tertiary Care Hospital: A Fifteen Month Prospective Study J Clin Diagn Res. 2012 Nov;6(9):1504-9.

6. Gupta S, Nayak RP, Shivaranjani R. A questionnaire study on the knowledge, attitude and the practice of Pharmacovigilance among the healthcare professional in a teaching hospital in south india. Perspective in clinical research. Jan-Mar 2015;6(1).

7. Chetty S, Parida A, Adiga S, Bairy KL. Knowledge, attitude and practice of health care professionals towards adverse drug reaction reporting in a south Indian teaching hospital. World Journal of Pharmaceutical Research. 2014;3(3):4271.

8. Sivadasan S, Sellappan M. A study on the awareness and attitude towards Pharmacovigilance and adverse drug reaction reporting among nursing students in a private university, Malaysia. International Jour. Of Current Pharmaceutical Research. 2015;7(1).

9. Şencan N, Altınkaynak M. The Knowledge and Attitudes of Physicians and Nurses towards Adverse Event Reporting and the Effect of Pharmacovigilance Training: A Hospital experience. Hacettepe University Journal of the Faculty of Pharmacy. 2010;30(1):25-40.

10. Kumari S, Saxena A. Evaluation of Knowledge Awareness and Attitudes Practice among nurses in Pharmacovigilance at tertiary care hospital Delhi. Journal of Harmonized research. 2015;4(1):76-86.

11. Bhagavathula AS, Elnour AA, Jamshed SQ, Shehab A. Health Professionals' Knowledge, Attitudes and Practices about Pharmacovigilance in India: A Systematic Review and Meta-Analysis. PloS one. 2016 Mar;11(3):e0152221.

Cite this article as: Hingorani S, Mehta C, Gajera P, Srivastava SK. Educational intervention to improve knowledge, attitude and practice of pharmacovigilance among nursing staff in tertiary care hospital. Int J Basic Clin Pharmacol 2017;6:1806-9. 